\title{
Fenugreek Seed Oil
}

National Cancer Institute

\section{Source}

National Cancer Institute. Fenugreek Seed Oil. NCI Thesaurus. Code C107307.

The oil pressed or distilled from the seeds of trigonella foenum gracecum. Fenug reek seed oil has activity as a phytoestrogen and topical activity as an antimicrobial agent. 